\title{
Professionalism, School Facilities, and Students' Cognitive Performance in Science in Oyo State, Nigeria
}

\author{
Afolakemi Olasumbo Oredein ${ }^{1}$, Grace Taiwo Babalola ${ }^{2}$ \\ ${ }^{1}$ Department of Educational Management, Faculty of Arts \& Education, Lead City University, Ibadan, Oyo State, Nigeria \\ ${ }^{2}$ Department of Science \& Technology, Faculty of Education, University of Ibadan, Ibadan, Oyo State, Nigeria
}

Email address:

opefolake1@yahoo.com (A. O. Oredein),gtbabss@yahoo.com (G. T. Babalola)

\section{To cite this article:}

Afolakemi Olasumbo Oredein, Grace Taiwo Babalola. Professionalism, School Facilities, and Students' Cognitive Performance in Science in Oyo State, Nigeria. Teacher Education and Curriculum Studies. Vol. 5, No. 3, 2020, pp. 94-102. doi: 10.11648/j.tecs.20200503.17

Received: June 7, 2020; Accepted: June 18, 2020; Published: July 17, 2020

\begin{abstract}
Science plays a fundamental role in the contemporary society with the potential to improve lives gaining impetus to research works. The influence of professionalism and school facilities on students' cognitive performance in science subjects in secondary schools in Oyo State was investigated. This was a descriptive survey research which was questionnaire based. The population of the study was all the public secondary schools (science teachers and students) in Oyo State, Nigeria. Purposive, cluster and simple random sampling techniques were used to select twenty public schools from each of the six educational zones in Oyo State making a total of one hundred and twenty schools, all science teachers (male and female) making a total of three hundred and sixty but three hundred and forty-two questionnaires were retrieved ( $95 \%$ of the sampled), and a total of eight thousand, two hundred and eighty science students from the selected schools were considered in the study. In each of the schools selected for the study, only science teachers were involved in the sample and the students that registered and wrote Biology, Chemistry and Physics WAEC examination of May/June 2018 in Oyo State, Nigeria. The data collected for the study were analyzed using descriptive statistics like percentage and mean, Multiple Regression analysis (ANOVA) and t-test. All the hypotheses were tested at 0.05 level of significance. The study revealed that there was significant combined influence $\left(\mathrm{F}_{1,340}=16.786 ; \mathrm{p}<0.05\right)$ of teachers' professionalism (professional disposition, professional discipline, professional development and professional experience) and school facilities (wellequipped laboratories, library, classrooms and conveniences) on science students' academic performance in Oyo State. It is recommended that professionalism should be reflected in the teaching of science subjects in secondary schools, training and re-training should be encouraged, and that the school environment should be made conducive for teaching-learning activities.
\end{abstract}

Keywords: Professionalism, School Facilities, Students' Cognitive Performance, Science Subjects, Oyo State, Nigeria

\section{Introduction}

Science is the center for any nation to develop socioeconomically. There is no way one can talk about any developed nation without mentioning science. Knowledge of science also develops creativity in its recipients that will lead to self-reliant [4]. Growth of any nation is a degree of its advancement in the area of science and technology respectively [17]. Some developed countries like; Russia, America, Japan, and China to mention few are as a result of the solidity in the area of science and technology. Science subjects are the base upon which the science and technological advancement of any nation is built [17]. It was reported that
Science is the principle upon which the technology is built, without science; there cannot be hunch for technology [16]. Hence, Nigeria as a nation needs a remarkable improvement in the area of science and technology.

With the understanding of the benefits that Science offer, the Federal Government of Nigeria has a target of $60 \%$ admission for her citizenry for science oriented courses in tertiary institutions [6]. It is rather unfortunate that the percentage that are annually admitted for science and related programmes is very low. This is as a result of the students' poor performance in their external examinations. Table 1 reveals the students' WASCE result for the period of six years (2012 to 2017). 
Table 1. Performance of Students in senior Secondary Certificate Examination Science Subjects (Credit and above) (2012-2017) in Oyo State.

\begin{tabular}{|c|c|c|c|c|c|c|c|c|c|c|}
\hline \multirow{2}{*}{ Year } & & \multicolumn{2}{|l|}{ Biology } & \multicolumn{3}{|c|}{ Chemistry } & \multicolumn{2}{|l|}{ Average } & \multicolumn{2}{|c|}{ Physics } \\
\hline & & A1-B3 & C4-C6 & A1-B3 & & C4-C6 & A1-B3 & C4-C6 & Mean & \\
\hline Sat & Total Sat & $\%$ & $\%$ & Total Sat & $\%$ & $\%$ & Total & $\%$ & $\%$ & \\
\hline 2012 & 43164 & 1.36 & 15.02 & 12748 & 3.20 & 20.81 & 13724 & 11.84 & 54.05 & 1.41 \\
\hline 2013 & 43164 & 1.36 & 15.26 & 12750 & 3.20 & 30.55 & 13724 & 11.84 & 53.70 & 1.44 \\
\hline 2014 & 24098 & 1.71 & 23.57 & 13808 & 6.00 & 37.46 & 18467 & 3.06 & 25.72 & 1.36 \\
\hline 2015 & 19371 & 2.68 & 27.97 & 13919 & 8.86 & 36.04 & 13758 & 5.80 & 26.46 & 1.42 \\
\hline 2016 & 19942 & 13.87 & 53.81 & 15144 & 17.66 & 53.32 & 15448 & 12.11 & 52.62 & 1.83 \\
\hline 2017 & 11698 & 7.74 & 52.54 & 13307 & 27.54 & 53.79 & 9701 & 5.38 & 46.04 & 1.78 \\
\hline
\end{tabular}

Note: $0-1.49=$ Low Level; $1.50-2.49=$ Average Level; $2.50-3.00=$ High Level

Source: Ministry of Education Report, Oyo State, 2018

Table 1 presents the analysis of students' cognitive performance in science subjects. The result shows that the average mean of students' cognitive performance in science subjects in 2012, 2013, 2014, and 2015 were low (1.41, 1.44, 1.36, and 1.42 respectively), while 2016 and 2017 were average (1.83 and 1.78 respectively). Also, the result show that the number of students offering science subjects has reduced which could be due to so many reasons. It was a known fact before that if anyone with a credit pass in any five related subjects to the course applied for in any university will secure an admission but it is not so these days, only students with A and B grades can be sure of gaining admission into the desired course in many universities especially first public generation universities.

This menace is of great concern to scholars, especially science educators. Previous studies have investigated various techniques of instructional delivery to ameliorate the students' poor performance, still, the problem persists. Therefore, researchers submitted that educational resources may be the main issue $[8,10]$. It was opined that educational resources in secondary school include students, personnel (teaching and administrative), physical facilities, curriculum and finance [10]. Studies on the impact of educational resources are a mix bag. Some researchers reported that educational resources have no significant impact on students' academic performance in secondary school $[8,10]$ while others reported significant impact of education resources on students' academic performance [18]. Since there is inconclusiveness and no previous studies have studied the effect of professionalism and school facilities on students' cognitive performance in Oyo State so there is need for this study.

Teaching is the most underestimated and non-recognized profession in the world especially in developing countries. Education teaching personnel are the teachers. Teachers are at the foremost of any educational system. No education system can thrive above the quality of its teachers $[23,20]$. The quality of a teacher hinges on the level of the teacher's professionalism. Professionalism or competency is one of the skills advocated for the 21 st century teachers. Much premium is placed on professionalism as the teachers' role in the realization of curriculum objectives cannot be over-stressed. Several definitions of professionalism abound in literature as there are studies on the concept of professionalism [8]. In this paper, teacher professionalism refers to the dispositions expected to be displayed of someone who has received a specified training on the field, discipline, development as in training and retraining, and experience acquired over time.

It is expected that teachers in public schools should be employed based on the professional qualifications knowing fully well the role teachers paly in achieving the educational goals. This is done with the credence that such teachers possess all it takes in the realization of the school curricular objectives apart from the fact that they have good mastery of their subject and skills to deliver. But students' cognitive performance in recent time seems not to match this belief. This has shown in an incessant report on students' low cognitive performance in science subjects [5]. One may assume that many of such public school teachers are not aware of not being qualified to teach science subjects, or not aware of the professional dispositions on the field: or have failed to apply that knowledge acquired during training.

Professional dispositions encompass maintaining appropriate relationships with students and colleagues, acceptable appearance and attitudes such as having a strong conviction that all students can learn [7]. Research works have shown that many of these dispositions do not significantly correlate with students' performance [10]. When the morale of a teacher is low it is likely to perform below the expected in the school system. According to a study carried out, the various problems infiltrating against the entire educational system in Nigeria such as cultism, examination malpractices, drug abuse, indiscipline, persistent poor academic performance of students in public examinations and many more seem to suggest that teachers have not been carrying out their job as expected [22]. Also, a study showed that there is a significant positive correlation between students' achievement and teachers' disposition [21]. Moreover, there is empirical evidence that advocated that teacher inputs have impact on students' performance [17].

The efficacy of the school facilities in students' cognitive performance especially in science subjects which is more of practical than theory cannot be over-emphasized. The school facilities are the heart and the soul of a school $[9,13]$. The effectiveness of school and its success in achieving its set goals are closely attached to the school facilities [11]. Teachers in a positive school environment where educational 
facilities are adequately provided mostly likely exhibit positive behaviour which is more lenient, influential, supportive, warm and concerned towards learners. Students will likely be existed and demonstrated self-direction and freedom towards learning. Students with comfortable school environment are better motivated to learn and exhibit behaviour which is positive towards learning [11]. It is equally evident that learning is more effective when sensory experiences are stimulated.

Having a close look at the physical environment of many public schools in Oyo State, and even Nigeria at large presents a sorry sight with awful dilapidated buildings, dingy classrooms devoid of seats and writing tables, and lack of or non-functional instructional materials, bad conveniences for both the staff and learners, non-functional library, non-well equipped science laboratories for practical, among others. Oyo State is one of the six southwestern states in Nigeria. Teachers in Oyo State, sometimes go to classes to teach learners virtually without instructional materials, thereby, teaching in abstract, as the concepts taught are not presented or brought into the realities of the learners. The lessons are dry, uninteresting and boring to learners; even the entire school system seems to be a waste of time and not worthwhile to the learners. In the light of this, only few serious students struggle and strive to memorize or cram concepts taught just to pass examinations, while a large proportion of the students perform poorly academically especially in external examinations.

The shortage of classrooms in many schools especially in public schools where the best supposed to be found being the government owned schools is so acute that more than sixty learners occupy classrooms that are meant for about thirty students according to the UNESCO recommendation. In most public schools, based on observation as teachers and experience gathered during teaching practice supervision, classroom furniture and other classroom facilities are grossly inadequate. Where classes are overcrowded, neither the teacher nor the learner can move freely as expected in secondary classrooms and which can lead to survival of the fittest. This is why many teachers failed to give assignments to such large number of learners regularly thinking of the stress to mark which in turn has negatively affected the outputs of educational school system. In such overcrowded classrooms, the experience amidst the learners will be 'survival of the fittest' while the low learners might not be taken care off. Even in some public schools classes are being taken under the trees because of the dilapidated classrooms where classroom roofs have removed may be by the wind and not replaced. Students have to carry tables and chairs from respective homes to school and with names written on such furniture. While students without furniture will have to manage with friends otherwise, stand by the window to receive classes.

Modern library is an indispensable school facility in the teaching-learning activities. Modern library is shifting from a transactional to a relational library which creates more values to students. Modern library is a place where information is easily accessible to both students and teachers. Library facilities in most Nigerian schools may be described as unsatisfactory. Library without current books and not even conducive for reading comparing with what a 21 st century educational library should look like. Most of the books in the library are not current but rather outdated and are not in conformity with the new curriculum and subjects taught in school. This situation depicts that students are discouraged from cultivating reading culture which is highly indispensable to writing skills, research and national development.

Likewise, it has been observed that school facilitates also influence students' academic performance in secondary school. School facilities are other essential education resources/materials used in the school to make teaching stress-free and learning more meaningful and understandable to the students. Such school facilities include: classrooms, white marker boards, teaching aids, libraries, laboratories, workshops, school farmland, health facilities, separate conveniences for both teachers and students, sport and recreational facilities, computer, and electricity supply among others. Research reported that school facilities correlate significantly on students' academic performance [15]. Based on this study, the school facilities are science laboratories, library and classroom condition.

\section{Statement of Problem}

Science plays a vital role in the lives of individuals and socio-economic development of every nation. The Federal Government of Nigeria is making efforts that her youngsters are science inclined but yearly performance in science is not encouraging. Scholars have devised different teaching techniques to combat this problem still the desired target has not been realized. Researchers then suggested that educational resources as the major issue. Reports on the influence of education resources on students' academic performance have been inconsistent. It is against this background that this study investigated the influence of professionalism and school facilities on students' academic performance in Oyo State.

\section{Research Questions}

1. What is the qualification of teachers teaching science subjects in public secondary schools in Oyo State?

2. What is the availability level of school facilities (library, classroom, and conveniences) in public secondary schools in Oyo State?

3. What is the availability level of the science laboratories apparatus in public secondary schools in Oyo State?

\section{Hypotheses}

1. There will be no significant combined influence of teachers' professionalism (professional disposition, discipline, development, and experience) and school facilities (well-equipped laboratories, modern library, 
classroom condition, and conveniences) on science students' cognitive performance in Oyo State.

2. There will be no significant relative influence of:

a) teachers professional disposition,

b) teachers professional discipline,

c) teachers professional development,

d) teachers professional experience,

e) well-equipped laboratories,

f) modern library,

g) classroom condition, and

h) conveniences on science students' cognitive performance in Oyo State.

\section{Methodology}

This study employed descriptive survey research design which was questionnaire based and past WAEC $\mathrm{O} / \mathrm{L}$ results (May/June 2012 to 2017) of the science (biology, chemistry and physics) students involved in the study in Oyo State, Nigeria. In this study, population comprised all public secondary schools (science teachers and students) in Oyo Sate, Nigeria.

Multi stage, purposive, cluster and simple random sampling techniques were used to select the samples. The first stage, all public secondary schools in Oyo State were divided into six educational zones and schools clustered in the six educational zones. The second stage, twenty public schools were randomly selected from each of the six educational zones in Oyo State making one hundred and twenty (120) schools. The third stage was the selection of teachers and science students. All the science teachers (360) in each of the selected schools participated in the study but three hundred and forty-two (342) were retrieved (95\% sampled). Having randomly selected sixty-two (62) science students from each selected schools, a total of eight thousand, two hundred and eighty $(8,280)$ Science students (male and female) were considered in the study. A result format was developed to collect the students' results that registered and wrote Biology, Chemistry and Physics WAEC examination of May/June 2012 to 2017 in Oyo State.

The study was carried out with the use of a structured questionnaire titled 'Professionalism and School Facilities' (PASF) and result format was used to collect Past WAEC $\mathrm{O} / \mathrm{L}$ results. PASF contained three sections; section $\mathrm{A}$ contained items on respondents' demographic data, section B contained items on school facilities and section $\mathrm{C}$ contained items on professionalism indices. Validation of the instrument was carried by administering the instrument to ten science teachers that were not part of the samples which is known as a pilot study. Also, the questionnaire was thoroughly scrutinized by four science educators from two colleges of education in the state for its face and content validity. The ratings of the four science educators were subjected to Fleiss' Kappa Inter-rater reliability scale. A reliability index of 0.75 was obtained.

\section{Results}

Research Question 1: What is the qualification of teachers teaching science subjects in secondary schools in Oyo State?

Table 2. Teachers' Highest Qualification.

\begin{tabular}{lll}
\hline Qualification & Frequency & Percentage (\%) \\
\hline NCE & 34 & 9.9 \\
HND & 12 & 3.5 \\
B. Sc & 149 & 43.6 \\
B. Ed/B. Sc (Ed) & 108 & 31.6 \\
HND/B. Sc with PGDE & 14 & 4.1 \\
M. Ed/M. Sc (Ed) & 16 & 4.7 \\
PhD & 9 & 2.6 \\
\hline
\end{tabular}

Source: Fieldwork, 2019

The table 2 shows the qualification of the teachers teaching science subjects in public secondary schools in Oyo State. The result revealed that about $36 \%$ teachers (B. Sc Ed./B. Ed) care certified or have the correct qualification to teach science subjects, while about $44 \%$ has B. Sc which is not the right certificate for teaching. Although about $10 \%$ has National Certificate in Education (NCE) but the NCE certificate is meant for both primary and junior secondary schools. This implies that less than half of those teaching science subjects in public secondary schools in Oyo State are not certified teachers and not properly trained to teach. Others who are not certified teachers may be teaching because of the growing unemployment in the country or who could not find jobs in other sectors easily.

Research Question 2: What is the availability level of school facilities (library, classroom, and conveniences) in secondary schools in Oyo State?

Table 3. Level of School Facilities.

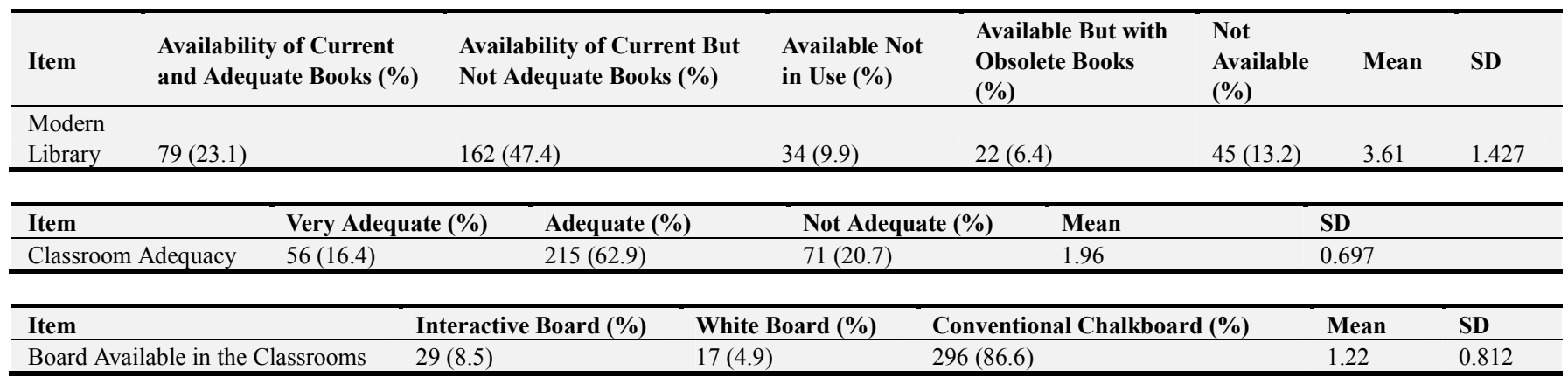




\begin{tabular}{|c|c|c|c|c|c|c|c|c|}
\hline Item & \multicolumn{2}{|c|}{ Fully Electrified (\%) } & Averagely Electrified (\%) & \multicolumn{3}{|c|}{ Not Electrified (\%) } & Mean & SD \\
\hline Electrification of School & $19(5.6)$ & \multicolumn{2}{|c|}{$105(30.7)$} & \multicolumn{3}{|c|}{$218(63.7)$} & 1.42 & 0.790 \\
\hline Item & $20-30(\%)$ & $31-40(\%)$ & $41-50(\%)$ & $51-60(\%)$ & & nd above $(\%)$ & Mean & SD \\
\hline Student-teacher Ratio Per Class & $40(11.7)$ & $79(23)$ & $89(26.1)$ & $69(20.1)$ & & $9.1)$ & 2.88 & 1.312 \\
\hline Item & $\begin{array}{l}\text { Available and } \\
\text { Adequate (\%) }\end{array}$ & $\begin{array}{l}\text { Available But } \\
\text { Not Adequate } \\
(\%)\end{array}$ & $\begin{array}{l}\text { Available But } \\
\text { Not in Use (\%) }\end{array}$ & $\begin{array}{l}\text { Available } \\
\text { Not in Go } \\
\text { Condition }\end{array}$ & & $\begin{array}{l}\text { Not Available } \\
(\%)\end{array}$ & Mean & SD \\
\hline Conveniences for Students & $35(10.2)$ & $92(26.9)$ & $-(0)$ & $90(26.3)$ & & $125(36.6)$ & 2.48 & 1.462 \\
\hline Conveniences for Teachers & $46(13.5)$ & $105(30.7)$ & $-(0)$ & $90(26.3)$ & & $101(29.5)$ & 2.72 & 1.490 \\
\hline
\end{tabular}

Source: Fieldwork, 2019

Table 3 reveals the level of school facilities (modern library, classroom condition, and conveniences) in public secondary schools in Oyo State, Nigeria. It was revealed that $47 \%$ has modern library with availability of current books but not adequate, and $13 \%$ do not have modern library at all. The implication of the finding is that science students will not be able to consult current books. Also, the result showed that the adequacy level of classrooms is low with the weighted mean of 1.96 and 3.30. This is reflected in the student-teacher ratio, where the highest student-teacher ratio was $26 \%$ having 41 to 50 students in a class which is against the UNESCO recommendation of 30-35. Moreover, on the electrification of the classrooms, the level of the electrification is very low with the weighted average of 1.42 against 3.3 ; about $64 \%$ public secondary schools in Oyo State were not electrified. And electricity is very important for science practical, no wonder that some teachers said that practical is done towards examination period when interviewed, so, there is no regular practical as scheduled on the time table. Also, the result showed that more public schools still parade the school with the use of conventional chalkboard. $87 \%$ public secondary schools in Oyo State still make use of conventional chalkboard to teach in this $21 \mathrm{st}$ century. The table also shows the availability level of conveniences in the public secondary schools. The weighted average for the availability level of conveniences was relatively high (2.48 and 2.72 against 2.0 for students and teachers respectively). Although the conveniences were available but about $37 \%$ and $30 \%$ (students and teachers respectively) were not in good condition.

Research Question 3: What is the availability level of the science laboratories basic apparatus in public secondary schools in Oyo State?

Table 4. Laboratories Basic Apparatus Availability Level.

\begin{tabular}{|c|c|c|c|c|c|c|c|}
\hline Basic Apparatus & $\begin{array}{l}\text { Available and } \\
\text { Adequate (\%) }\end{array}$ & $\begin{array}{l}\text { Available Not } \\
\text { Adequate (\%) } \\
\end{array}$ & $\begin{array}{l}\text { Available Not } \\
\text { in Use }(\%)\end{array}$ & $\begin{array}{l}\text { Available Not in } \\
\text { Good Condition (\%) }\end{array}$ & $\begin{array}{l}\text { Not Available } \\
(\%)\end{array}$ & Mean & S. D \\
\hline Safety goggles and equipment & $32(9.4)$ & $69(20.2)$ & $93(27.2)$ & $77(22.5)$ & $71(20.7)$ & 2.75 & 0.661 \\
\hline Beakers & $22(6.4)$ & $41(12.1)$ & $79(23.1)$ & $91(26.6)$ & $109(31.8)$ & 2.34 & 0.721 \\
\hline Conical flasks & $45(13.2)$ & $82(23.9)$ & $39(11.4)$ & $21(6.1)$ & $155(45.4)$ & 2.53 & 0.611 \\
\hline Boiling flasks & $79(23.1)$ & $189(55.3)$ & $19(5.6)$ & $34(9.9)$ & $21(6.1)$ & 3.79 & 0.618 \\
\hline Test tubes, tongs and racks & $31(9.1)$ & $121(35.4)$ & $64(18.7)$ & $66(19.3)$ & $60(17.5)$ & 2.99 & 0.741 \\
\hline Watch glasses & $55(16.1)$ & $153(44.8)$ & $33(9.5)$ & $86(25.2)$ & $15(4.4)$ & 3.43 & 0.560 \\
\hline Funnels & $18(5.3)$ & $64(18.7)$ & $57(16.7)$ & $94(27.5)$ & $109(31.8)$ & 2.38 & 0.701 \\
\hline Graduated cylinders & $21(6.2)$ & $56(16.4)$ & $74(21.6)$ & $37(10.8)$ & $154(45.0)$ & 2.28 & 0.796 \\
\hline Volumetric flasks & $14(4.1)$ & $27(7.9)$ & $33(9.7)$ & $74(21.6)$ & $194(56.7)$ & 1.81 & 0.903 \\
\hline Droppers & $39(11.4)$ & $21(6.1)$ & $19(5.6)$ & $41(12.1)$ & $222(64.8)$ & 1.87 & 0.912 \\
\hline Pipettes & $22(6.4)$ & $41(12.1)$ & $79(23.1)$ & $91(26.6)$ & $109(31.8)$ & 2.35 & 0.711 \\
\hline Burets/burette & $34(9.9)$ & $64(18.7)$ & $79(23.1)$ & $32(9.4)$ & $133(38.9)$ & 2.51 & 0.811 \\
\hline Ring stands, rings \& clamps & $37(10.8)$ & $56(16.4)$ & $74(21.6)$ & $21(6.2)$ & $154(45.0)$ & 2.42 & 0.721 \\
\hline Thermometers & $39(11.4)$ & $109(31.8)$ & $59(17.2)$ & $41(12.1)$ & $94(27.5)$ & 2.88 & 0.768 \\
\hline Bunsen burners & $15(4.4)$ & $55(16.1)$ & $33(9.5)$ & $86(25.2)$ & $153(44.8)$ & 2.10 & 0.737 \\
\hline Balances & $39(11.4)$ & $135(39.5)$ & $17(5.0)$ & $69(20.2)$ & $82(23.9)$ & 2.94 & 0.845 \\
\hline Syringe & $88(25.7)$ & $91(26.6)$ & $11(3.2)$ & $19(5.6)$ & $133(38.9)$ & 2.95 & 0.751 \\
\hline Cover slides & $21(6.1)$ & $72(21.1)$ & $39(11.4)$ & $62(18.1)$ & $148(43.3)$ & 2.29 & 0.723 \\
\hline Petri dish & $21(6.1)$ & $70(20.5)$ & $39(11.4)$ & $45(13.2)$ & $167(48.8)$ & 2.22 & 0.696 \\
\hline Microscope & $65(19.0)$ & $94(27.5)$ & $57(16.7)$ & $107(31.3)$ & $19(5.5)$ & 3.23 & 0.562 \\
\hline Magnet & $79(23.1)$ & $189(55.3)$ & $19(5.6)$ & $34(9.9)$ & $21(6.1)$ & 3.79 & 0.501 \\
\hline Lenses & $41(12.1)$ & $155(45.4)$ & $55(16.0)$ & $49(14.2)$ & $42(12.3)$ & 3.30 & 0.532 \\
\hline Forceps & $19(5.5)$ & $62(18.1)$ & $32(9.4)$ & $29(8.5)$ & $200(58.5)$ & 2.03 & 0.711 \\
\hline Scalpel & $15(4.4)$ & $55(16.0)$ & $79(23.1)$ & $21(6.1)$ & $172(50.3)$ & 2.18 & 0.721 \\
\hline Sweep net & $21(6.1)$ & $72(21.1)$ & $39(11.4)$ & $62(18.1)$ & $148(43.3)$ & 2.29 & 0.801 \\
\hline Quadrat & $29(8.5)$ & 27 (7.9) & $63(18.4)$ & $55(16.0)$ & $168(49.1)$ & 2.11 & 0.788 \\
\hline Dissecting kits & $21(6.1)$ & $52(15.2)$ & $39(11.4)$ & $69(20.2)$ & $161(47.1)$ & 2.13 & 0.791 \\
\hline
\end{tabular}




\begin{tabular}{|c|c|c|c|c|c|c|c|}
\hline Basic Apparatus & $\begin{array}{l}\text { Available and } \\
\text { Adequate (\%) }\end{array}$ & $\begin{array}{l}\text { Available Not } \\
\text { Adequate (\%) } \\
\end{array}$ & $\begin{array}{l}\text { Available Not } \\
\text { in Use (\%) }\end{array}$ & $\begin{array}{l}\text { Available Not in } \\
\text { Good Condition (\%) }\end{array}$ & $\begin{array}{l}\text { Not Available } \\
(\%)\end{array}$ & Mean & S. D \\
\hline $\begin{array}{l}\text { Preserved specimens } \\
\text { Weighted Mean }=2.51\end{array}$ & $11(3.2)$ & $55(16.0)$ & $15(4.4)$ & $39(11.4)$ & $222(64.9)$ & 1.81 & 0.908 \\
\hline
\end{tabular}

Source: Fieldwork, 2019

Note: Mean ranges from $0.00-1.49=$ Not Available; $1.50-2.49=$ Available Not in Good; Condition; $2.50-3.49=$ Available Not in Use; $3.50-4.49=$ Available Not Adequate; $4.50-5.00=$ Available and Adequate

Table 4 shows the science laboratories basic apparatus. The weighted mean (2.51) is between the range of available but not in use. The result reveals that so many public schools have the basic apparatus in the science laboratories but not in use. This implies that those basic apparatus are being used occasionally which may be due to lack of electricity. Boiling flasks has the highest mean (3.79) of availability, followed by watch glasses (3.43), followed by lenses (3.30) while preserved specimens, volumetric flasks, spatulas and scoopulas had the least mean (1.81) of availability.

Hypothesis 1: There will be no significant combined influence of teachers' professionalism (professional disposition, discipline, development, and experience) and school facilities (well-equipped laboratories, modern library, classroom condition, and conveniences) on science students' cognitive performance in Oyo State.

Table 5. ANOVA.

\begin{tabular}{|c|c|c|c|c|c|c|c|c|}
\hline Model & Sum of Squares & Df & Mean Square & $\mathbf{F}$ & Sig. & & & \\
\hline Regression & 1844.23 & 1 & 1844.23 & & $\mathrm{R}$ & $\mathrm{R}^{2}$ & Adj. $\mathrm{R}^{2}$ & $\mathrm{SE}$ \\
\hline Residual & 11096.75 & 340 & 109.869 & 16.786 & $0.000^{\mathrm{a}}$ & .778 & .643 & .613 \\
\hline Total & 12940.98 & 341 & 2.395 & & & & & \\
\hline
\end{tabular}

$* \mathrm{p}<0.05$

Table 5 presents the analysis of combined influence of teachers' professionalism (professional disposition, discipline, development, and experience) and school facilities (well-equipped laboratories, modern library, classroom condition, and conveniences) on science students' cognitive performance in Oyo State. The table shows that teachers' professionalism and school facilities have significant combined influence on science students' cognitive performance $\left(\mathrm{F}_{1,340}=16.786 ; \mathrm{p}<0.05\right)$. Hence, the null hypothesis is rejected because the $\mathrm{p}$-value was less than the 0.05 level of significance. $\mathrm{R}^{2}$ which is the co-efficient of determination shows that the independent variables that are, teachers' professionalism and school facilities accounted for a high proportion of about $64 \%$ of science students' cognitive performance in science subjects. Also, the standard error of the estimated means is 2.395. This implies that factors are relevant towards the determination of the dependent measure. This is in line with the research outcome of a study that, the combined factors can predict the academic performance of the science students [5]. Also, this finding is in consistent with another study that teachers' professionalism is directly proportional to students' academic performance [14].

Hypothesis 2: There will be no significant relative influence of: a) teachers' professional disposition, b) teachers' professional discipline, c) teachers' professional development, d) teachers' professional experience, e) wellequipped laboratories, f) modern library, g) classroom condition, and h) conveniences on science students' cognitive performance in Oyo State.

Table 6. Coefficients.

\begin{tabular}{lllllll}
\hline \multirow{2}{*}{ Dependent Variable } & \multirow{2}{*}{ Independent Variables } & \multicolumn{2}{c}{ Unstandardized Coefficient } & Standardized Coefficient & \multirow{2}{*}{ S } & \\
\cline { 3 - 5 } & & B & Std. Error & Beta Contribution & 4.385 & 0.000 \\
& (Constant) & 1.731 & 0.395 & & 0.128 & 3.742 \\
& Professional Disposition & 0.030 & 0.021 & 0.183 & 0.005 \\
& Professional Discipline & 0.038 & 0.013 & 0.617 & 0.088 & 0.005 \\
Students Academic & Professional Development & 0.030 & 0.024 & 0.362 & 0.014 \\
Performance in & Professional Experience & 0.149 & 0.025 & 0.415 & 3.595 & 0.000 \\
Science Subjects & Well Equipped Laboratories & 0.167 & 0.022 & 0.306 & 5.921 & 0.000 \\
& Modern Library & 0.130 & 0.101 & 0.168 & 1.431 & 0.012 \\
& Classroom Condition & 0.942 & 0.104 & 0.376 & 2.862 & 0.004 \\
& Conveniences & 0.755 & 0.112 & 0.081 & 1.286 & 0.155 \\
\hline
\end{tabular}

Source: Fieldwork, 2019

Table 6 shows the relative influence of the eight (8) indicators of independent variables on the dependent variable, expressed as beta weights, viz: professional disposition $(\beta=$ $0.128, \mathrm{p}>0.05)$; professional discipline $(\beta=0.617, \mathrm{p}<0.05)$; professional development $(\beta=0.362, \mathrm{p}<0.05)$; professional experience $(\beta=0.415, \mathrm{p}<0.05)$; well-equipped laboratories $(\beta$ $=0.306, \mathrm{p}<0.05) ;$ modern library $(\beta=0.168, \mathrm{p}<0.05)$; classroom condition $(\beta=0.376, p<0.05)$ and conveniences $(\beta$ $=0.081, \mathrm{p}>0.05)$. The results on the table shows that while professional discipline, professional development, 
professional experience, well-equipped laboratories, modern library and classroom condition were significant with cognitive performance of science students, professional disposition and conveniences were not significant on science students cognitive performance. The table revealed that professional discipline has the highest influence $(\beta=0.617)$ on science students cognitive performance, followed by professional experience $(\beta=0.415)$, followed by classroom condition $(\beta=0.376)$, followed by professional development $(\beta=0.362)$, followed by well-equipped laboratories $(\beta=$ $0.306)$, and modern library $(\beta=0.168)$. Professional disposition $(\beta=0.128)$ and Conveniences $(\beta=0.081)$ had the least influence on science students cognitive performance in Oyo State.

\section{Discussion}

The results of the study were discussed based on the research questions and hypotheses stated:

Table 2 showed that the highest qualification of teachers teaching science subjects is B. Sc with a frequency of 149 $(43.6 \%)$. This is followed by B. Sc Ed/B. Ed with a frequency of $108(31.6 \%)$, NCE is with a frequency of 34 $(9.9 \%)$ and $\mathrm{PhD}$ had the least frequency of $9(2.6 \%)$. This implies that there were more unqualified teachers in the public secondary schools in Oyo State teaching science subjects. The only sets of people who are qualify to teach science subjects in secondary schools are people with B. Sc $\mathrm{Ed} / \mathrm{B}$. Ed, or M. Ed/M. Sc Ed, or HND with PGDE. NCE is meant to teach primary and junior secondary school students.

Table 3 revealed that many public secondary schools in Oyo state have modern library but books were not enough (47.4\%) for students to read and only few schools (13.2\%) do not have library. This implies that both science teachers and students do not access to information as expected. Also, the result shows that the classroom condition level was low with the weighted average of 1.96 against 3.3 ; this was also confirmed in the student-teacher ratio where 41-50 was the highest $(26.1 \%)$. This implies that the science class was congested and this can lead to 'survival of the fittest'. It is possible that brilliant students will have no problem while the average or slow learners might be grossly affected because teachers might not be able to have much time for those sets of students. The electrification of the classroom was very poor, majority of the public schools were not electrified (63.7\%). Electricity is an essential school facility for science students because of the practical classes. This implies that teachers will not be holding practical classes regularly as scheduled on the time table but rather engage in 'fire brigade approach' that is, students will only be prepared for external examination only which is not the best for good understanding of the concept taught. Moreover, majority of the public secondary schools were still using the conventional chalkboard $(86.6 \%)$ to teach in this 21 st century when teaching-learning activities have shifted from the conventional method of teaching. There is a paradigm shift in the teaching-learning activities. It was also discovered that many of the public secondary schools do not have conveniences for both the teachers and students $(36.6 \%$ and $29.5 \%$ ) respectively. This implies that the environment of such schools will be too dirty; too much odour and it will not be conducive for learning. This study corroborated with researchers' report that school facilities have significant influence on learners' academic achievement [1, 19]. Moreover, many secondary schools in Oyo State have adequate science laboratory apparatus but not in use. Practical classes only take place when external examination period is closer.

The combined influence of predictor variables on science students' cognitive performance is high, positive and statistically significant at 0.05 level $\left(\mathrm{F}_{1,340}=16.786 ; \mathrm{p}<0.05\right)$. The coefficient of determination $\left(\mathrm{R}^{2}\right)$ is 0.643 . This implies that about $64 \%$ variation in science students' cognitive performance is jointly explained by variation in the predictor variables. The remaining $36 \%$ unexplained variation is largely due to variation in other variables which are not included in the regression model but otherwise constitute the stochastic error term. This study supported the study carried out that professionalism is directly proportional to students' academic performance [14].

Testing the impact of the relative predictor variables on science students' cognitive performance, the result shows that only the impact of professional discipline $(\mathrm{t}=2.088$, $\mathrm{p}<0.05)$, professional development $(\mathrm{t}=1.247, \mathrm{p}<0.05)$, professional experience $(\mathrm{t}=3.595, \mathrm{p}<0.05)$, well-equipped laboratories $(\mathrm{t}=5.921, \mathrm{p}<0.05)$, modern library $(\mathrm{t}=1.431$, $\mathrm{p}<0.05)$, and classroom condition $(\mathrm{t}=2.862, \mathrm{p}<0.05)$ on science students' cognitive performance were significant at $5 \%$ confidence level in each case. However, the impact of professional disposition $(\mathrm{t}=3.742, \quad \mathrm{p}>0.05)$ and conveniences $(t=1.286, p>0.05)$ on science students' cognitive performance were not significant at $5 \%$ confidence level in each case. The results corroborated with the findings of some researchers' report [14, 13, 19].

The secondary school system being an open system is cyclic in nature, and just like any other social organizations, it absorbs inputs from the environment and discharges output to the environment [17]. And it is this level of education that feeds the tertiary institutions, hence, the need for great concern from all stakeholders and most especially in the area of science. Results from research works serve as a pointer to detect any shortfall in educational development so as to specify corrective measure (s) for planners for quality teaching process [17]. A study posited that if educational inputs are inferior, the output will also be inferior and this will affect the performance of the system [2]. In this case, professionalism and school facilities are catalyst of transformation based on the outcome of this study. If the transformation is not properly effected may be as a result of the underestimation and non-recognition of professionalism in education and poor school facilities, the outputs will be defective. 


\section{Conclusion}

Professionalism and school facilities are very important factors in determining the quality of education that science students can receive. As such, governments (federal, state, and local levels) have great responsibility to ensure that professionalism is treaty with due recognition and uncertified teacher should not be allowed to teach in schools. Uncertified teachers who are already teaching should be exposed to proper training and regular re-training for certified teachers.

Science students are discouraged because of the poor school facilities and learning is taken place through struggles and manages to scale through secondary school. Learning is much on theory than practical because there were no wellequipped science laboratories and students were only prepared for external examination, so, practical classes take place only when external examination approaches. Teachers are incapacitated and confined to discharge of duties in a seemingly uncultured, porous and unplanned school environment [3].

\section{Recommendations}

Based on the findings of this study the following recommendations were made:

i. Professionalism in education should be accorded with due recognition and respect by the governments (federal, state and local levels), all education stakeholders and the communities.

ii. Governments should also look into the school facilities by making sure that the suggestion of the UNESCO on student-teacher ratio (30:1 or at most 35 to 1 ) is adhere to for teaching effectiveness and efficiency.

iii. School environment should be made conducive for learning by providing modern library, well-equipped science laboratories, good electrification, good conveniences, and providing more classrooms for learning while dilapidated ones should be reconstructed.

iv. Parents Teachers Association (PTA), Alumni, and NGOs should be involved in the recommendations ii and iii.

\section{References}

[1] Ahmodu, O.; Lateef, A. O.; and Shehu, A. A. (2018). Impact of School Facilities on Students' Academic Performance in Oshodi-Osolo L. G. A. Senior Secondary Schools, Lagos State. Available: http://www.researchgate.net

[2] Akindutire, I. O. (2001). The Teaching Profession. Ado Ekiti: Green Line Publisher.

[3] Akinnola F. nd Oredein, A. O. (2019). School Climate Indices as Predictors of Teachers' Job Satisfaction and Performance in Oyo State, Nigeria. Paper Presented During the WERA-Japan International Conference, August (Unpublished).

[4] Babalola, G. T. (2018). Instructional Congruence, Know-
Want-Learn Strategies and Students' Learning Outcomes in Basic science in Oyo State, Nigeria. PhD Thesis, University of Ibadan, Ibadan, Oyo State, Nigeria. (Unpublished).

[5] Babayemi, J. O., Utibe, U. J. and Babalola, G. T. (2018). Teaching Skills in Basic Sciences: Implication for Quality Teacher Education Programmes and Learners' Acquisition of Life Skills for Building a Safer World. CARD International Journal of Educational Research and Management Technology (IJERMT), 3 (2), 1-11. Available: $\mathrm{http} / /$ www.casirmediapublishing.com

[6] Bilesanmi-Awoderu, J. B and Oludipe, D. I. (2012). Effectiveness of Cooperative Learning Strategies on Junior Secondary Students' Academic Achievement in Basic Science. British Journal of Education, Society \& Behavioural Sciences 2 (3), 301-325.

[7] Brehm, B., Breen, P., Brown, B., Long, L., Smith, R., Wall, A., and Warren, N. S. (2006). Instructional design and assessment. An interdisciplinary approach to introducing professionalism. American Journal of Pharmaceutical Education, 70 (4), 1-5.

[8] Creasy, K. L. (2015). Defining Professionalism in Teacher Education Programs. Journal of Education \& Social Policy, 2 (2), $23-25$

[9] Ekundayo, H. T. (2019). School Facilities as Correlates of Students' Achievement in the Affective and Psychomotor Domains of Learning. European Scientific Journal, 8 (6), 208215.

[10] Fabunmi, M. (2012). Resources Input Quality and Quantity as Determinants of Secondary School Students' Academic Performance in Edo State, Nigeria (1989-1994). African Journal of Educational Research, 8 (1\&2), 50-57.

[11] Fauzilah, S.; Noryati, Y.; and Zaharah, D. (2011). The influence of Skill Levels on Job Performance of Public Service Employees in Malaysia. The Business \& Management Review, 1 (1), 31-40.

[12] Federal Republic of Nigeria (2004). National Policy on Education. NERDC Press, Yaba, Lahos, Nigeria.

[13] Ibrahim, W. Y.; Umar, H. A. and Clement, I, (2017). Impact of School Facilities on Students' Academic Achievement. International Journal of Advanced Research 5 (12), 878-889. Available: http://dx.doi.org/10.21474/IJAR01/6034

[14] Khan, A.; Khan, S.; and Khan, M. (2017). Teaching Professionalism and Students Academic Achievements. Research on Humanities and Social Science. 7 (7), 47-52.

[15] Mcgowen, R. S. (2007). The Impact of School Facilities on Student Achievement, Attendance, Behavior, Completion Rate and Teacher Turnover Rate in Selected Texas High Schools. A Dissertation Submitted to the Office of Graduate Studies of Texas A\&M University in partial fulfilment of the requirements for the degree of Doctor of Philosophy (Unpublished).

[16] Ogungbemi, E. (2005). Science and Technology in Society. Science Journal School of Sciences, College of Education, Ikere, Ekiti.

[17] Oredeiin, A. O. and Awodun, A. (2013). Impact of Teachers' Motivational Indices on Science Students' Academic Performance in Nigerian Senior Secondary Schools. International Education Studies, 6 (2), 49-54. 
[18] Osuji, J. N. (2016). Impact of School Facilities on Students' Academic Performances in Public Secondary Schools in Giwa and Zaria Education Zones, Kaduna State, Nigeria. A Dissertation Submitted to the School of Postgraduate Studies, Ahmadu Bello University, Zaria. In partial fulfillment of the requirements for the award of Master's Degree in education (Educational Administration And Planning), Department of Educational Foundations and Curriculum, Faculty of Education. Ahmadu Bello University, Zaria, Nigeria (Unpublished)

[19] Owoeye, J. S. and Yara, P. O. (2011). School Facilities and Academic Achievement of Secondary School Agricultural Science in Ekiti State, Nigeria. Asian Social Sciences 7 (7), 211-223.

[20] Singh, D. K. and Stoloff, D. L. (2007). Measuring Teacher Dispositions. Being A Paper Presented at the National Fifth Annual Symposium on Educator Dispositions Erlanger, Kentucky.
[21] Soric, T. M. (2011). The Impact of Teacher Attitudes on Academic Achievement in Disadvantaged Schools. A Dissertation Submitted as partial fulfilment of the requirements for The Master of Education Degree in Educational Theory and Social Foundations The University of Toledo (Unpublished).

[22] Usman, Y. D. (2016). Educational Resources: An Integral Component for Effective School Administration in Nigeria. Research on humanities and Social Sciences, 6 (13), 27-37. Available: www.iiste.org

[23] Welle, B. (2010). Background Experiences and Dispositions of Teachers that Predict Student Outcomes in Elementary Schools. An Unpublished $\mathrm{PhD}$ Thesis Submitted to the Department of Educational Leadership and Policy Studies and the faculty of the Graduate School of the University of Kansas in partial fulfillment of the requirements for the Award of Degree of Doctor of Education 